Article

\title{
Locating Leadership and Political Will in Social Policy: The Story of India's MGNREGA
}

\author{
Ujjwal Krishna * and Chris Roche \\ Institute for Human Security and Social Change, La Trobe University, Melbourne, VIC 3086, Australia; \\ E-Mails: u.krishna@latrobe.edu.au (U.K.), c.roche@latrobe.edu.au (C.R.) \\ * Corresponding author
}

Submitted: 15 June 2020 | Accepted: 30 September 2020 | Published: 25 November 2020

\begin{abstract}
The term 'political will' is often conveniently used to explain the success or failure of any policy or programme. It has emerged as the "sine qua non of policy success which is never defined except by its absence" (Hammergren, 1998, p. 12). Therefore, a structured examination of the term is necessary to analyse social policy and programming. The Mahatma Gandhi National Rural Employment Guarantee Act (MGNREGA), enacted by India's United Progressive Alliance government in 2005, offers a compelling case to examine the role of 'political will' in the formulation of a major programme. The evolution of the MGNREGA, which has been described by the World Bank as the largest antipoverty state-run employmentgeneration scheme anywhere in the world (Dutta, Murgai, Ravallion, \& van de Walle, 2014), depended significantly on leadership and political commitment in the legislature and the executive, as well as their coordination and substantive engagement with civil society, represented through non-governmental organisations and activists. We explore the complex power relations between the diverse range of actors involved in the MGNREGA, and gauge the role of leadership and political will in the formulation of the MGNREGA, as carried out by the United Progressive Alliance government between 2005 and 2014, in contrast to the manner in which it was reframed and retained by its successor dispensation, the National Democratic Alliance from 2014 onwards. We then examine the MGNREGA, utilising a framework which expands our understanding of political will as being contingent upon leadership at the individual, collective and societal levels (Hudson, Mcloughlin, Roche, \& Marquette, 2018), thereby providing us with greater explanatory power.
\end{abstract}

\section{Keywords}

coalitions; developmental leadership; employment; framing; India; leadership; MGNREGA; policy formulation; political leadership; social policy

\section{Issue}

This article is part of the issue "Leadership and Political Change in Asia-Pacific" edited by David Hudson (University of Birmingham, UK), Nicolas Lemay-Hébert (Australian National University, Australia), Claire Mcloughlin (University of Birmingham, UK) and Chris Roche (La Trobe University, Australia).

(C) 2020 by the authors; licensee Cogitatio (Lisbon, Portugal). This article is licensed under a Creative Commons Attribution 4.0 International License (CC BY).

\section{Introduction}

Upon being elected in 2004, India's United Progressive Alliance (UPA), a coalition led by the Indian National Congress party, began introducing various legallyenforceable rights with a view to increase economic and social opportunities for its citizens, of which the National Rural Employment Guarantee Act, 2005, later renamed as the Mahatma Gandhi National Rural Employment
Guarantee Act (MGNREGA) was its flagship program. The UPA:

Introduced numerous programmes to benefit poorer groups who had been largely ignored both by its main rival, the Bharatiya Janata Party [BJP], which had led a ruling coalition between 1998 and 2004, and by the Congress itself in earlier periods. (Manor \& Duckett, 2017, p. 306-307) 
The MGNREGA:

Sought to protect the livelihoods of the poor agricultural labourers during periods of distress, by granting adult members of every rural household the right to demand [at least] 100 days of [guaranteed] unskilled work at stipulated minimum wages from the state. (Vijayabaskar \& Balagopal, 2019, p. v)

The Mahatma Gandhi National Rural Employment Guarantee Scheme that operates under the aforementioned Act, came into force in February 2006, following the enactment of the MGNREGA in August 2005, and it was phased-in across India in three steps in a "highly non-random manner that prioritized economically underdeveloped districts" (Zimmermann, 2013, p. 3). After initially being implemented in the first 200 poorest districts of India, the scheme was extended to the rest of the country with 130 additional districts receiving it in April 2007, and all remaining rural districts by April 2008 (Ministry of Rural Development, 2010).

MGNREGA has been described as the largest antipoverty state-run employment-generation scheme anywhere in the world (Dutta et al., 2014). It registers 270.5 million active workers, and reaches 693 out of India's 718 districts, spanning 265,067 Gram Panchayats, which are elected village-level local self-governing institutions (Ministry of Rural Development, 2020a), that are entrusted with rural development: "Work is provided in public works projects at the statutory minimum wage notified for the programme by State Governments that are responsible for implementing the [MGNREGA]," and this "work must be made available within 15 days of receiving an application to work, failing which, the State Government is liable for paying an unemployment allowance" (Dutta et al., 2014, p. xxiii). The MGNREGA was initially conceptualized amongst civil society activists in the state of Rajasthan in the early 2000s, recognizing the need for a public works program to combat drought (Chopra, 2011), and was eventually introduced by the Indian National Congress-led central government in 2005.

Essentially it is a public works programme that is planned through a bottom-up, decentralised process, with half of the works implemented through Gram Panchayats at the village-level (Chopra, 2011). It is a demand-led Act, with resources transferred from the central to state governments based on the demand for employment in each state, assessed through periodical surveys conducted by the Gram Panchayats. The assured employment for one hundred days at minimum wages guaranteed by the MGNREGA to a rural household is a right that can be expected, demanded and legally enforced. In addition to short-term employment generation the MGNREGA also creates durable assets like productive infrastructure for poverty alleviation (Second Administrative Reforms Commission, 2006). Given that the MGNREGA is demand-driven, there are no state-wise allocations. Instead:
Releases are based on labour budget estimates prepared at the start of the year and the actual demand for work during the year...[and] total funds available for [the MGNREGA] include [Government of India] and state government releases, as well as, unspent balances from previous years. (Accountability Initiative, 2020a)

With the UPA government losing the 2014 Indian general election, the National Democratic Alliance (NDA), led by the centre-right BJP came to power. The BJP's ascendance raised a number of question marks over whether the MGNREGA would be continued, particularly since its welfare narrative, focusing on 'empowerment,' pointedly differed from the Congress' which emphasised on 'rights' and 'entitlements' (Aiyar, 2018). Even though the BJP maintained ideological opposition to the Congress' conceptualization of employment generation, and favoured individual effort as opposed to state support, it has not only retained the MGNREGA but has also overseen its growth.

Figure 1 contains revised estimates of budgetary allocations to the Ministry of Rural Development (in blue), and allocations to the MGNREGA as a proportion of the overall ministerial budget for each financial year since the programme's inception. It is clear that while there has been some ebb and flow in allocations during the UPA years up until 2014, there has since been a broadly upward trend in allocations by the NDA since FY 2014-2015. It must be noted that revised estimates are used since they present a more accurate picture compared to budget estimates, since:

Some of the estimates made by the government might change during the course of the year, [and that] once the year gets underway, some ministries may need more funds than what was actually allocated to them in the budget, or the receipts expected from certain sources might change. (Tiwari, 2019)

In terms of outcomes, both household-level and personwise employment indicators, as seen in Figure 2, have similarly seen a broadly upward trend since the NDA government took office in 2014, across the categories of demand for work, allotment of work, and actual numbers worked, save for a slight dip in total persons demanding and being allotted work in FY 2017-2018. MGNREGA employment data has been analysed here from FY 2011-2012 up until FY 2019-2020, since comparable categories of data for previous financial years are not available, and figures for the current FY 2020-2021 are provisional, with data being available only for part of the year on the MGNREGA Public Data Portal (Ministry of Rural Development, 2020b).

Even though the employment data shows an overall upward trend since FY 2014-2015 in terms of total demand, allocation, and actual work undertaken, metrics such as total person-days generated, and the total 


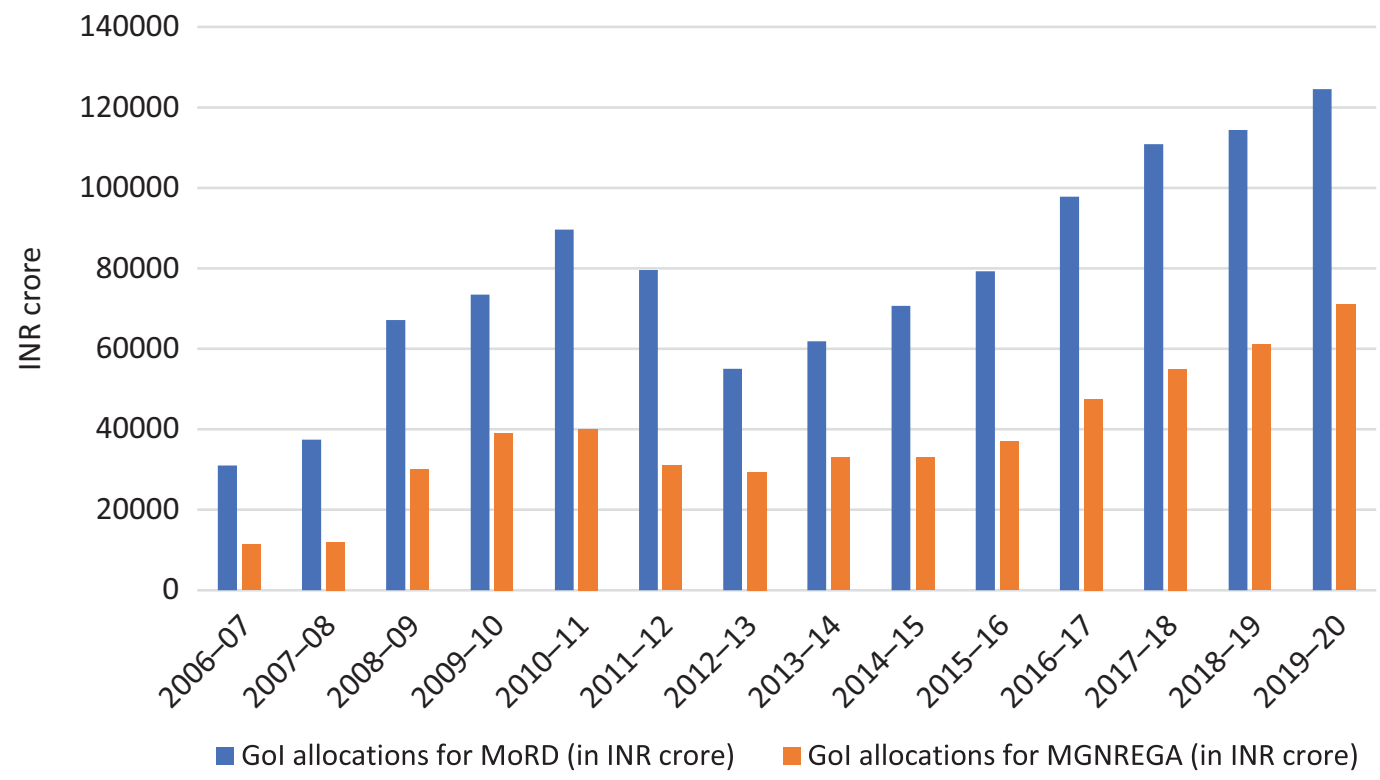

Figure 1. Union expenditure budget of the Ministry of Rural Development for FY 2006-2007 to FY 2019-2020. Note: Figures in Rupees crore ( 1 crore $=10$ million) and are revised estimates (constructed from data in public domain). Source: Accountability Initiative (2020b).

number of households reaching the prescribed 100-day limit, provide a relatively mixed picture, as is clearly visible in Figure 3. The labour budget estimate under the MGNREGA is contingent upon the amount of total cost (towards wage, material, and administrative costs) to be incurred while generating a person-day wage employment, and as such, this fact lends significance to the use of person-days as an indicator. On the other hand, the 100-day limit for MGNREGA is a useful indicator as well, and arguably a more representative measure of the programme delivering on the letter and spirit of what the MGNREGA guarantees to the rural poor. In terms of both total person-days and total households having reached the 100-day limit, no clear trend is visible, and hence

(a)

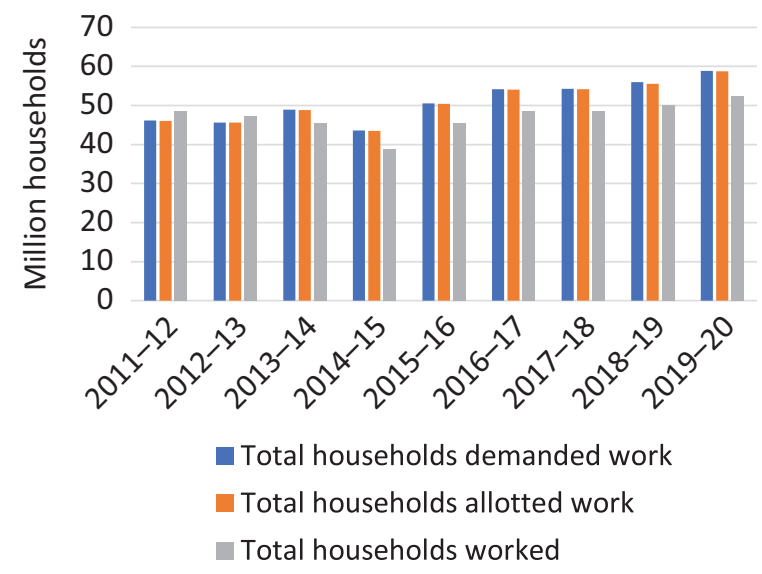

the overall employment figures (demand, allocation, and actuals) need to be viewed in perspective. This is because while these may provide an aggregate picture, the data in Figure 3 unpacks them in a way that shines greater light on salient programmatic features prescribed by the MGNREGA, and by its operational guidelines (Ministry of Rural Development, 2013).

Therefore, what emerges from the data is that at least in terms of demand for, allocation of, and actually undertaken public works at both the household and individual levels, there has been a largely upward trend since the NDA took office in 2014. This upward trend has also been mirrored in rising budgetary allocations. Even though this trend is not identical for total person-

Figure 2. Total household demand for work, allotted work, and actually worked (a), juxtaposed against total persons demanded work, allotted work, and actually worked (b). Note: Figures in million Rupees (constructed from data in public domain). Source: Ministry of Rural Development (2020b). 
(a)

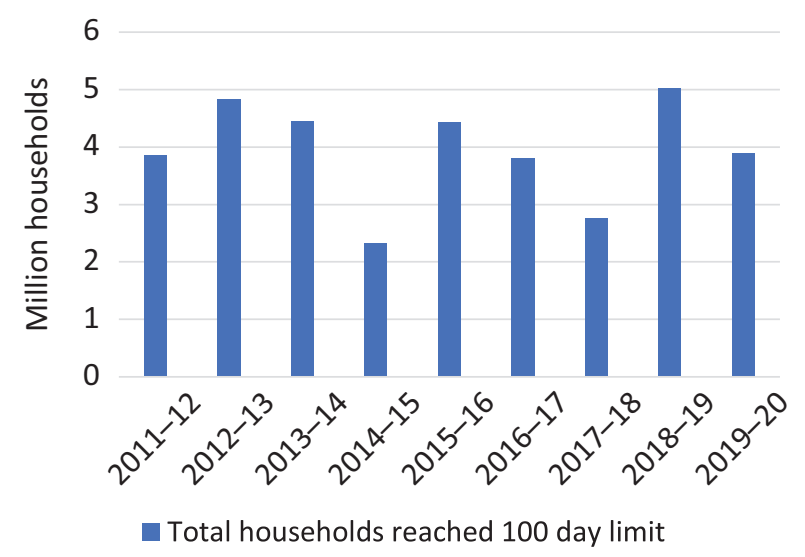

(b)

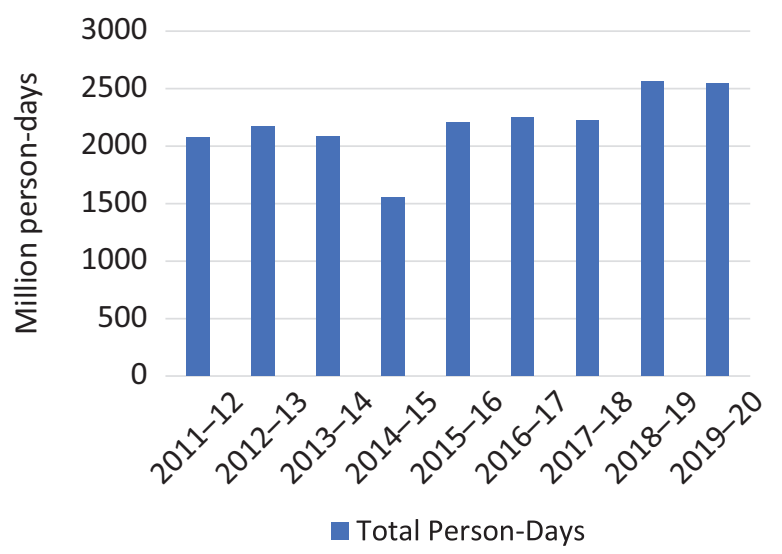

Figure 3. Total households that reached the 100-day limit (a), juxtaposed against person-days generated (b). Note: Figures in million Rupees (constructed from data in public domain). Source: Ministry of Rural Development (2020b).

days generated, and the number of households that reached the 100-day limit, what is unmistakable is that the BJP-led government, despite its publicly-stated distaste for the ideological basis of the MGNREGA (Pankaj, 2017), has not only retained the programme, but has overseen its growth. In this article, we explore how political actors formulated, framed, and re-framed the MGNREGA in the UPA and NDA dispensations, by unpacking the concept of 'political will.' The literature on the programme to date does not examine the motivations behind the political framing and re-framing of the programme in a structured manner: The focus has largely been on programme implementation. While there has been some exploration of the political leadership of the scheme (Manor \& Duckett, 2017), this has used crosscountry comparative analysis across a broader sweep of national antipoverty programmes, and as such has not sufficiently examined the case of the MGNREGA itself. We begin by interrogating the concept of 'political will' and reviewing the literature surrounding its usage and operationalization, as well as the literature on the role of leadership in the MGNREGA, introducing a framework of 'developmental leadership' (Hudson et al., 2018), which we argue provides for greater explanatory power by expanding the typical definitions of political will. Following that, we conclude with a comparison of the evolution of the MGNREGA under the UPA and the NDA through the categories proposed by the 'developmental leadership' framework.

\section{Interrogating 'Political Will'}

'Political will' remains a highly ambiguous concept, described variously as "the slipperiest concept in the policy lexicon," and the "the sine qua non of policy success which is never defined except by its absence" (Hammergren, 1998, p. 12). It has been frequently used in the Indian context, ranging from leading bankers attributing the sclerotic pace of economic reforms to the lack of 'political will' to undertake them ("Lack of political will," 2014), to the requirement of 'political will' to reduce India's neonatal mortality rates ("Save our babies," 2018), as well as to the centrality of 'political will' in the implementation of India's family planning programme (Gwatkin, 1979). The ambiguity in its meaning lends value to the term as political rhetoric, since in the absence of a clear causal diagnosis, policy failure can be conveniently labelled as a failure of 'political will' (Post, Raile, \& Raile, 2010). Nevertheless, there is no consensus as to what constitutes 'political will' in each of these cases, and while the role of 'political will' can be seen to be relevant in the popular imagination for the success or failure of any government programme or scheme, a structured examination of the term is necessary to operationalise it.

At times, 'political will' is defined in a markedly individual actor-driven manner based on commitment, intent or willingness, such as by the UK's erstwhile Department for International Development (2004, p. 1), which considered it "the determination of an individual political actor to do and say things that will produce a desired outcome." The origins of this understanding of 'political will' can be traced to Kpundeh (1998, p. 92), who argued that it is the "demonstrated credible intent of political actors to attack perceived causes or effects...at a systematic level," and to Brinkerhoff (2000, p. 242), who proposed that it is the "commitment of actors to undertake actions to achieve a set of objectives...and to sustain the costs of those actions over time." Individual-centric notions of political will are echoed by Anderson, Branchflower, Moreno-Torres, and Besançon (2005), who consider it to be willingness which can be assessed by commitment and inclusiveness, and Rose and Greeley (2006, p. 5), who argued that it is the "sustained commitment of politicians and administrators to invest political resources to achieve specific objectives." One of the principal precedents of "political will' that have been suggested in the Department 
for International Development (2004, p. 1) are imagination on the part of the politician or policymaker, that is "some capacity to envision how things might be different." Personality traits and styles have an impact on the choices made by leaders, and to understand them, and the pathways they enable, there is a need to delve into the psychology of leaders and the manner in which it motivates them to pursue developmental change (Corbett, 2019).

'Political will' can also be understood at a collective level, with Brinkerhoff (2007) linking the term to state capacity by arguing that the fundamental nature of capacity development is as an "endogenous process that engages not just the abilities and skills, but the motivation, support, and aspirations of people" (p. 111), or in other words, the "ownership and/or political will" (p. 112), although cautioning that "it is problematic to accurately identify ownership and political will, and to differentiate these two volitional components from capacity questions" (p. 112). Chopra (2015), while focusing on the MGNREGA's performance in terms of its implementation across four states, builds upon a political economy perspective in which institutions, actors and incentives are delineated (Mcloughlin \& Batley, 2012), and the role of politics is considered crucial (Leftwich \& Wheeler, 2011). In this vein, Chopra extends Brinkerhoff (2000)'s framework for understanding the commitment of actors involved in programme implementation, which consists of two principal elements-'action' and 'intention.' Similarly, Post et al. (2010) attempt an expanded understanding of political will by including "incentives or disincentives" (p. 655), "bargaining mechanisms" (p. 664), "credibility...(based on reputational costs)" (p. 660), and "political or social institutions or...aspects of human behaviour" (p. 655) as key determinants. Moreover, Andrews, McConnell, and Wescott (2010) suggest in their work on leadership-led change that the acceptance of change, granting authority for change, and introducing or freeing the abilities necessary to achieve change, are crucial, and that leadership is therefore more about collective rather than individual action.

Post et al. (2010, p. 658) in a similar vein describe the conceptual components of 'political will' by extracting three categories of the conceptual components of 'political will' through an examination of the previous definitions of the complex, multifaceted term. These include (1) the "distribution of preferences with regard to the outcome of interest," the (2) "authority, capacity, and legitimacy of key decision makers or reformers," and (3) the extent of "commitment to preferences" with regard to the policy action in question. In this sense 'political will' requires enough people in positions of power who support the policy or programme in question, and an insufficient number of veto players who may potentially block or derail it (Roberts, 2017), which assumes greater significance in large democracies like India where there are "typically more complex arrays of supporters and veto players" (Roberts, 2017). The intensity of the policymakers' commitment to supporting a policy or programme therefore hinges upon factors ranging from their most influential constituencies, the pressure groups lobbying them and the intensity of their preferences in turn, the ideological underpinnings as implicit in their party membership, as well as larger cultural preferences (Roberts, 2017), thereby marking the importance of collective interests.

Hudson et al. (2018, p. 8) have recently argued that:

The key to opening the black box of political will lies in the interaction between institutions and individuals, or structures and agents, [and]...requires a move from a static and reductionist view of institutions initiated and sustained by 'political will,' to a more dynamic and temporal view of politics as a process of contestation to establish the 'collective will.'

What emerges from the multiple definitions of 'political will' that have been discussed in this section is that there are essentially three categories or levels which might be described as the (1) individual, the (2) collective, and the (3) societal. Even though the literature, as distilled above discusses what can be termed the individual and the collective levels quite extensively, the societal aspect is somewhat less well-articulated.

This definition holds that 'political will' depends on the developmental (positive) leadership of motivated individuals with the values, interests and opportunity to influence change, as well as their ability to overcome barriers to cooperation and form coalitions with power, legitimacy, and influence, while these coalitions' power and effectiveness partly hinges on their ability to contest and de-legitimise one set of ideas and legitimize an alternative set (Hudson et al., 2018). However, "typically, though not exclusively, [this] involves a process of active contestation where various stakeholders within society enter into debate and conflict-though not necessarily violence" (Hudson et al., 2018, p. 9) over distributional consequences, as well as the fairness of outcomes concerning existing or proposed institutional rules, or both (Beetham, 1991; Mcloughlin, 2015). It is argued that it is the "outcome of this political process of contestation [which] is that leaders and coalitions accrue power to reformulate institutions in ways that are perceived as locally legitimate and sustainable" (Hudson et al., 2018, p. 12). We use this three-level conceptual framework to explore the puzzle of the maintenance and growth of the MGNREGA under the NDA.

\section{Comparing the MGNREGA under the UPA and NDA}

\subsection{Motivations of Individuals}

The centre-left UPA government, led by the Congress, and supported through a confidence-and-supply arrangement with the Left Front parties until 2008, came 
to power in May 2004 after winning the 2004 Indian general election, dislodging the previous BJP-led NDA government which was in power from 1998 to 2004. The idea of an employment guarantee had been an important feature of the Congress's 2004 election manifesto which made an explicit policy commitment by way of the MGNREGA (Indian National Congress, 2004). The Congress president, Sonia Gandhi, widely expected to assume the premiership following her party's election victory, in a surprise move, relinquished the position of prime minister to Manmohan Singh, her key lieutenant and former Indian finance minister in prime minister PV Narasimha Rao's cabinet from 1991 to 1996 . Singh was credited for his leadership and technocratic finesse in spearheading the crucial economic reforms that liberalised India's economy in 1991 in the face of a looming and potentially debilitating balance-of-payments crisis, heralding an end to India's 'Licence-Permit Raj,' as its complex web of bureaucratic controls was popularly described, and implementing a simultaneous across-theboard reduction of import tariffs (Baru, 2014).

While Singh was chosen to preside over the central government, Sonia Gandhi would chair the UPA, as well as the National Advisory Council (NAC), the latter consisting of members who, while designing the MGNREGA, utilised ideas generated by "prolonged encounters in Rajasthan state between civil society organisations and state governments (some of which were Congress-led)" (Manor \& Duckett, 2017, p. 308). This dual model was partly due to Sonia Gandhi not being "intimately familiar with administrative matters," yet being motivated in the policies that emerged from the NAC she chaired to go "much further than previous Congress governments in addressing poverty, [since] she regarded them as efforts to lend substance to the dynasty's claims to be progressive" (Manor \& Duckett, 2017, p. 318). These efforts stemmed from her experience of observing from close quarters her mother-in-law, prime minister Indira Gandhi's "(mostly empty) promises to tackle poverty" and what has been described by some observers as her husband, prime minister Rajiv Gandhi's "inept and confused" leadership, throughout which she "had acquainted [herself] with the progressive rhetoric of the Congress Party" (Manor \& Duckett, 2017, p. 317-318).

The MGNREGA:

Formed the cornerstone of the shift in the UPA's approach to development towards universalization and entitlements, articulated in the National Common Minimum Programme which committed the different constituent political parties of the coalition towards delivering on the basis of a cohesive policy framework. (Krishna, 2019, p. 9)

Even as the Congress party:

Exercised great power within the ruling coalition that it led between 2004 and 2014...it was allied to many (mainly regional) parties, some of which had only limited interest in poverty initiatives...[and] Prime Minister Singh and some of his key colleagues were sceptical and eventually even hostile to certain poverty programmes that Congress leader Sonia Gandhi supported. (Manor \& Duckett, 2017, p. 309)

Over a long academic and bureaucratic career, Singh had served as chief economic advisor, secretary in the finance ministry, Reserve Bank of India governor, Planning Commission deputy chairman, and later in politics as finance minister and leader of the opposition in the upper house of Parliament. Baru (2014) describes Singh as enthusiastically receiving the scheme once it reached his office through the NAC. However, in line with his background and technocratic motivations, he "resisted demands for linking wages in the [MGNREGA] to a minimum wage and wage indexation" (Singh, 2014), even though, owing to the nature of his relationship with the NAC chair, he acquiesced to the NAC's demands.

The centre-right BJP-led NDA government came to power in May 2014, and installed Narendra Modi, who had till then served as chief minister of the western Indian state of Gujarat, as prime minister. Individually far less committed to the MGNREGA, Modi, and arguably most of the BJP cadres, lent very little personal ideological support to the MGNREGA, as exemplified by the prime minister's remarks on the floor of the Lok Sabha, the lower House of Parliament, which betray his lack of 'political will,' that he would keep the MGNREGA alive as a 'living monument' of the failures of the Congress for making people dig holes after 60 years of Independence (Joshua \& Sriram, 2015). This served the dual objective of indicating his ideological distaste for the scheme, while leaving open the option of retaining it if necessary.

\subsection{Collective Action}

The NAC was a body formed to oversee the implementation of the National Common Minimum Programme which consisted of "various distinguished professionals drawn from diverse fields of development activity," and was "envisaged...as a form of interface with civil society and government, thereby positioning this party-political domain as having a window in civil society and parliamentary domains" (Chopra, 2011, p. 160). Manor and Duckett (2017, p. 312) outline how "progressive intellectuals and civil society leaders [were in] potent roles in the policy-making process for the first time-most notably in the NAC that Sonia Gandhi chaired," as well as the important role of "progressive bureaucrats." Chiriyankadanth, Maiorano, Manor, and Tillin (2020) describe the boundaries between different actors as being blurred, with several activists, as well as bureaucrats, both then retired as well as currently occupying official policymaking roles at the time, being members of the NAC.

It elicited opposition from the central government itself over the MGNREGA's perceived fiscal irresponsi- 
bility, in view of its high annual expenditures which would typically constitute around 1 percent of Indian GDP (Zimmermann, 2013). During and after its formulation, contestation emerged over the MGNREGA in the form of the differences between the prime minister's office and the finance ministry on the one hand, and the NAC on the other as "related mainly to the financial implications of the programme with estimates of how much it would cost the exchequer varying from 1 to 3 percent of national income" (Baru, 2014, p. 142), with neither the prime minister nor the finance minister agreeing to an open-ended fiscal commitment given that the "benefits of the programme were to be based on self-selection" (Baru, 2014, p. 142). Conservative industrialists and landowners' "anxieties about heavy expenditures were shared by Prime Minister Manmohan Singh and officials in the finance ministry and helped to trigger cuts in the outlay for several poverty programmes, including the MGNREGA, in 2013-2014" (Manor \& Duckett, 2017, p. 313). The MGNREGA was envisioned as a 'targeted' programme in which rather than being dependent on an administrator to choose the beneficiaries, the programme "expects beneficiaries to select themselves by creating incentives so that only the poor will participate in the scheme," even though this self-selection or selftargeting mechanism is weak in instances of low awareness and the MGNREGA wage outstripping the prevailing market wage (Shankar \& Gaiha, 2013).

However, such criticism is tempered in view of the self-targeting mechanism's lack of incentive creation for misuse, "in that nonpoor people are unlikely to demand such work" (Dutta et al., 2014, p. xxiii). Moreover, procedural criticism over the NAC's structure and the disproportionate power it wielded needs to be viewed in perspective, with Chopra (2011) highlighting how these institutional mechanisms created much-needed further space for multiple actors and institutions to interact and exercise power during the formulation processes of the MGNREGA, ranging from activists and civil society networks like the People's Action for Employment Guarantee, to actors belonging to a variety of political parties and trade unions, with the NAC effectively being formed as a coalition of motivated individuals. The MGNREGA is a case which highlights that firstly, power is diffuse and has multiple sites where it is exercised; and secondly, that power works through complex and iterative ways, with overlaps in actors, the flow of information, and the congregative activities of the parliamentary, executive, party-political, and civil society domains, adding to the "complex and messy nature of policy formulation" (Chopra, 2011, p. 167).

Despite the UPA government being led by the centreleft Congress, it has been argued that the MGNREGA, when passed in 2005, was not entirely influenced by the neoliberal bent of an important segment of the executive leadership at the time. The role of the Left has been described by Chopra (2011, p. 162) as "intricately bound up with civil society actors as well as other stakeholders involved in the formulation processes, in addition to their explicit role in the parliamentary and executive domains." This reflected the fact that broader political alliances shaped the programme, with a firm basis in compromises as a result of differing ideas and political ideology. After the 2004 Indian general election, the UPA would not have been able to secure a majority without the Left Front parties' support, chief among them the Communist Party of India (Marxist), since forming a government is dependent on securing the support of more than half of the parliamentarians in the Lok Sabha. In such a context, the Left Front wielded 'disproportionate' influence over UPA policies until such time as they decided to discontinue their support to the UPA government following reservations over the terms of the Indo-US Civil Nuclear Agreement in 2008 (Krishna, 2019). The route for exercising this influence was through interventions during the negotiations of the UPA-Left coordination Committee, an inherently 'party-political' process (Chopra, 2011). At an ideological level, this party-political process was buoyed by several left-leaning actors in civil society and NAC processes, despite their lacking explicit Left Front party memberships (Chopra, 2011). Moreover, the UPA's alliance partners such as the Rashtriya Janata Dal, a regional party based in the northern Indian state of Bihar, supplied politicians such as Raghuvansh Prasad Singh, the union minister for rural development from 2004 to 2009, who acted as the "bridge between the [UPA's] fiscal conservatives and the populists" through his own personal networks and relationships (Baru, 2014, p. 142).

Since 2014, the BJP commanded a parliamentary majority in the Lok Sabha of its own accord and was logically "less beholden to [its] coalition partners [in the NDA] in formulating its policies" and programmes, which would reduce both accountability and collective constraints (Krishna, 2019, p. 9). Aiyar (2018) argues that since 2014, the NDA government has also exhibited strong signs of excessive centralisation of power in the Prime Minister's Office, with line ministries in direct contact with local district magistrates to tightly monitor implementation targets. This trend, coupled with the prime minister's highly personalised, charismatic leadership style, has also compromised the federal structure of governance and the attendant state-specific priorities and social policy innovation, and "increased activity has not been complemented by increased capacity and as districts lurch from one target to another, they have little time for monitoring quality" (Aiyar, 2018).

Moreover, the NDA "placed technology at the heart of its policy agenda, onboarding the UPA's Direct Benefit Transfer approach early on through its Jan Dhan-AadhaarMobile" trinity platform, essentially a troika of free bank accounts for all beneficiaries, a unique identification number, and mobile phone connectivity to streamline service delivery "with a view to migrating towards a cashbased welfare setup" (Krishna, 2019, p. 9). Such a Direct Benefit Transfer-centric approach has been described by commentators as an approach to gloss over, rather than 
overtly address, the "roots" of core governance "delivery failure" like "complex procedures, weak human resource, [and] poor training" (Aiyar, 2018).

\subsection{Societal Contestation and Deliberation}

The NAC allowed for the inclusion of several civil society activists in the process of creating the first draft of the National Rural Employment Guarantee Bill (Chopra, 2011). However, the influence and freedom that the NAC gained in crafting the UPA government's policies and programmes, stemming from what was perceived to be Sonia Gandhi's supreme authority in the political landscape of the country during the UPA years, also elicited criticisms of acting as an extra-constitutional authority. Through the media, this complex power equation led to widespread public discourse, leading to both the contestation and legitimation of, at a societal level, ideas of what constitutes legitimate politics and suitable social policy.

The MGNREGA was prominent among the legislations enacted between 2004 and 2009, the UPA's first full term in office, which included the Right to Information Act, 2005, and the Recognition of Forest Rights Act, 2006, among others. Electoral analysts have argued that with a seemingly "correct reading of the effects of economic reforms and the deployment of the aam adami [Hindi for 'common man'] language in 2004, a series of pro-people legislative and policy initiatives [such as the MGNREGA]" (Yadav \& Palshikar, 2009, p. 42) partly contributed to the Congress leading yet another coalition government at the centre with a considerably enhanced mandate. Manmohan Singh became the first prime minister after the inaugural holder of the office, Jawaharlal Nehru, to be re-elected after a full five-year term. According to Manor and Duckett (2017, p. 307), the UPA's election victory in $\mathbf{2 0 0 4}$ had been mistakenly attributed in the media to a "revolt among the rural poor against the policies of the previous BJP-led government." However:

The UPA set out to make that myth a reality at the next election, [and] had some success in achieving that, although that was also over-stated in media assessments in 2009...[with] its poverty initiatives, only some of which succeeded, [adding] up to a decidedly innovative approach. (Manor, 2011, as cited in Manor \& Duckett, 2017, p. 307)

Even though its impact on the UPA's victory in 2009 was partially attributable to the MGNREGA, it still considerably raised the costs of its discontinuation or dilution, thereby leading to a reasonable degree of institutional lock-in.

The media had "erroneously claimed that [the MGNREGA] won re-election for the ruling alliance in 2009, but it helped to ensure a majority that would survive until 2014 when scandals and political blunders sent it down to a severe election defeat" (Manor, 2011, as cited in Manor \& Duckett, 2017, p. 320). As the second term of the UPA government (2009 to 2014) grappled with allegations of corruption, extant problems with the scheme, such as states reneging on their employmentprovision commitments, wages being "delayed and withheld," and "a lack of proper social auditing and monitoring" resulting in corruption (Freud, 2015, p. 3), "were exacerbated by the UPA's overall image of policy paralysis and inaction" (Krishna, 2019, p. 9). During the UPA's second term it began 'dilly-dallying' with the idea of Direct Benefit Transfer programmes, in the run up to the 2014 parliamentary elections (Pankaj, 2017), and essentially set the scene for re-framing the MGNREGA towards a cash transfer-based setup which the NDA built upon further from 2014 onwards. The UPA proceeded to re-frame the scheme in this direction without first addressing the acute capacity and access-related concerns surrounding the delivery mechanisms of such an approach. While Manmohan Singh as prime minister had:

Persuaded cabinet colleagues in 2010 to make a change in the rules governing India's MGNREGA that undermined efforts by actors at lower levels to siphon off funds from the programme...by contrast, he permitted cuts in funds for that same programme after 2011 (which...contributed to his party's defeat at the 2014 election). (Manor \& Duckett, 2017, p. 322)

The 'cynical' process of 'starving' the MGNREGA of essential funds had begun in 2010 itself, through placing a cap on the funding allocated, which led to issues with paying wages and providing employment (Ghosh, 2015).

Despite its "pro-business and investment-oriented" framing, evident in its national-level drive to push such a narrative with initiatives such as "Make in India, Skill India, and Start-up India...as opposed to the 'entitlements' and 'rights'-oriented framework reminiscent of the Congress" (Krishna, 2019, p. 9), the NDA government has not abandoned the programme and budgetary allocations to it have seen a largely upward trend since it took office. Although simultaneously, the NDA has reframed the MGNREGA's emphasis towards 'asset creation' driven by targets and often in a 'top-down' or centralised manner (Pankaj, 2017), the 'polar opposite' of the UPA's conceptualization of the MGNREGA, which had pursued a "demand-driven job creation regime focused on participatory decentralised development" (Pankaj, 2017, as cited in Krishna, 2019, p. 9).

Therefore, important differences emerge in the formulation and framing of the MGNREGA between the NDA and the UPA, with the former responding to societal expectations of its declared ideological approach towards poverty programming by not mentioning the MGNREGA in its 2014 election manifesto, a programme towards which it maintains what is described by some observers as a 'hostile attitude' (Gowda \& Batra, 2019). The attendant re-framing by the NDA has been captured 
by Pankaj (2017) as tweaking the MGNREGA towards becoming 'asset-focused' against 'wage-focussed,' and 'target-focussed' at the cost of 'demand-focussed' which compromised its original emphasis on promoting 'participatory decentralised development' as envisaged by the UPA. Such 'asset fetishism' has disproportionately skewed the scheme's benefits towards agriculturists at the expense of landless labour, which has affected employment generation (Pankaj, 2017). "The UPA had prioritised job-creation over asset-creation by mandating a wage-material expenditure ratio of 60:40" (Pankaj, 2017, as cited in Krishna, 2019, p. 9), and mandated that four out of the eight works that the scheme covered are to be related to more labour-intensive work, with the remaining four works related to labour-intensive asset creation (Pankaj, 2017; Pawariya, 2017). Despite the NDA expressing:

Its intent to change the ratio of expenditure between labour and material from the current 60:40 applicable at the gram panchayat level to $51: 49$ applicable at the district level...[it] decided to maintain a 60:40 wage-material ratio at the district level...to ensure [the] creation of good quality assets in rural areas. (“MGNREGA wage-material ratio," 2016)

While noting that public policy and the nature and choice of development programmes pursued are not regimeneutral, Pankaj (2017) also illustrates that the NDA quelled 'lurking uncertainty' around the MGNREGA's continuation by attributing changes in the programme to itself, and declaring it:

A programme of "national pride and celebration" on the occasion of 10 years of its completion... [with then] Union Finance Minister, Arun Jaitley, [emphasising] that "transformation has been brought in the implementation of this Scheme," asserting further that the scheme is not "cast in stone." ("Modi government praises," 2016, as cited in Pankaj, 2017, p. 61)

\section{Conclusions}

In the Indian context, "most political parties...(with the exception of the communists) are founded not on a strong economic ideology but on notions of culture and identity-national, regional, ethnic, caste-based or linguistic" (Kotwal, Ghatak, \& Ghosh, 2014, p. 41), and "there is a lack of a one-to-one mapping between economic and social ideologies on either side of the political spectrum" (Krishna, 2019, p. 9). Kotwal et al. (2014, pp. 41-42) argue that:

Positions on economic policy are usually a derivative, influenced by vote bank calculations or the need to attract funds for election campaigns. Since policy choices do not arise from deep ideological commitments to preferred economic paradigms, they are often incoherent, shifting and lacking in the sort of essence that may qualify for labels like socialist or libertarian.

The political origin of antipoverty programmes has been based in "pragmatic calculations about [parties'] political utility," and even as "socialist or progressive ideals long espoused by ruling parties played a part, in [countries like] India, their time-honoured rhetorical commitments to socialist or social democratic ideals had not previously been translated into much robust action (Manor \& Duckett, 2017, pp. 310-311). "While lying on two opposite ends of the political spectrum, the Congress and the BJP have followed broadly the same paths in the pursuit of neoliberal policy" (Pankaj, 2017, as cited in Krishna, 2019 , p. 9), even though the Congress has adhered to the cautious, reforms-by-stealth route as opposed to what has been described as the BJP's faster and bolder approach (Pankaj, 2017). Manor and Duckett (2017, p. 311) argue that:

[The] traditional social democratic posturing of the Congress Party (including Indira Gandhi's promise to 'abolish poverty'), which had seldom been matched by substantive action, was again treated as a point of origin and was given substance for the first time.

Both the Congress and the BJP consider high rates of GDP growth to be synonymous with development, and while the Congress concedes to the need for state intervention in social sector development, the BJP subscribes to a trickle-down approach (Pankaj, 2017).

Considering these differences, the BJP has re-framed the programme away from the Congress's preference for a universal approach with the nationwide implementation of the MGNREGA, and away from a mixed portfolio of cash and kind transfers towards more targeted cashbased assistance (Pankaj, 2017). Despite the BJP's ideological aversion to the scheme, and a heightened propensity for veto players to exercise their derailment agenda, the institutional lock-in for the MGNREGA had already occurred. At a societal level, the MGNREGA's provision of income as a right in rural areas raised the political costs of the scheme's discontinuation or dilution. While one may have expected the cessation of the programme on ideological grounds, in fact the BJP has been unable to repeal in order to avoid electoral ramifications, particularly in rural areas. Budgetary allocations to the MGNREGA by the BJP, as well as employment indicators at the individual and household levels have seen largely upward trends since 2014.

Even though individual-level distaste for the MGNREGA may persist in the BJP, as evident in prime minister Narendra Modi's "making people dig holes" remark in parliament, the BJP has collectively identified the incentives for its retention. At an individual level, key UPA leaders and NAC members, from the top-down, were personally and openly committed to the idea of 
the MGNREGA, as demonstrated throughout the 2004 general election campaign and the Congress' manifesto. The NAC emerged as the site of collective deliberation for a coalition of motivated individuals, who hailed from a broadly similar ideological persuasion and therefore displayed a certain cohesion which helped resolve partypolitical differences between UPA allies.

With ideological commitment and programme formulation in relatively greater synchronisation, societal norms were shaped effectively, particularly in rural India, leading to the 'locking-in' of the programme which at the societal level formed a rights-based social contract with a concomitant expectation created for its retention (Chopra, 2014). As a result, despite individual and political contestation by the NDA, the MGNREGA was retained, although re-framed to better reflect the BJP's ideological approach towards poverty programming, the stage for which was partly set by the UPA in its second term by linking Direct Benefit Transfers with the MGNREGA. Therefore, while as a blanket term, 'political will' does not really explain much, expanding and reconceptualising its definition by analysing leadership at the individual, collective, and societal levels, helps illuminate the drivers behind the formulation, retention, framing, and re-framing of the scheme.

\section{Acknowledgments}

The authors would like to thank David Hudson, Academic Editor of this thematic issue, and two anonymous reviewers for their detailed comments and suggestions that have helped improve the quality of this work, as well as Amrita Saha at the Institute of Development Studies, University of Sussex, for reviewing its initial version. This article was presented at the annual conference of the Development Studies Association, organised by the University of Birmingham in June 2020, and we acknowledge the feedback received from fellow members of the panel on 'Critical perspectives on social protection and social policy reforms in developing countries.'

\section{Conflict of Interests}

The authors declare no conflict of interests.

\section{References}

Accountability Initiative. (2020a). Mahatma Gandhi national rural employment guarantee scheme (MGNREGS) Gol, 2020-21 (Budget Briefs Vol. 12/Issue 1). New Delhi: Centre for Policy Research.

Accountability Initiative. (2020b). Budget briefs. Centre for Policy Research. Retrieved from https:// accountabilityindia.in/budget-briefs

Aiyar, Y. (2018, May 26). Four years of Modi government: Confused priorities hit welfare strategy. The Hindustan Times. Retrieved from https://www. hindustantimes.com/analysis/four-years-of-modi- government-confused-priorities-hit-welfarestrategy/story-P3LiZva01jhn42svmaGQbJ.html

Anderson, M., Branchflower, A., Moreno-Torres, M., \& Besançon, M. (2005). Measuring capacity and willingness for poverty reduction in fragile states (PRDE Working Paper No. 6). London: Department for International Development.

Andrews, M., McConnell, J., \& Wescott, A. O. (2010). Development as leadership-led change: A report for the Global Leadership Initiative and the World Bank Institute (WBI) (HKS Working Paper No. RWP10-009). Cambridge, MA: Harvard Kennedy School.

Baru, S. (2014). The accidental prime minister: The making and unmaking of Manmohan Singh (1st ed.). New Delhi: Penguin.

Beetham, D. (1991). The legitimation of power (1st ed.). Basingstoke: Palgrave Macmillan.

Brinkerhoff, D. W. (2000). Assessing political will for anti-corruption efforts: An analytic framework. Public Administration and Development, 20(3), 239-252.

Brinkerhoff, D. W. (2007). Where there's a will, there's a way? Untangling ownership and political will in post-conflict stability and reconstruction operations. Whitehead Journal of Diplomacy and International Relations, 8, 111-120.

Chiriyankadanth, J., Maiorano, D., Manor, J., \& Tillin, L. (2020). The politics of poverty reduction in India: The UPA government, 2004 to 2014 (1st ed.). New Delhi: Orient Blackswan.

Chopra, D. (2011). Interactions of 'power' in the making and shaping of social policy. Contemporary South Asia, 19(2), 153-171.

Chopra, D. (2014). 'They don't want to work' versus 'They don't want to provide work': Seeking explanations for the decline of MGNREGA in Rajasthan (Working Paper No. 50). Manchester: University of Manchester.

Chopra, D. (2015). Political commitment in India's social policy implementation: Shaping the performance of MGNREGA (ESID Working Paper No. 50). Manchester: University of Manchester. Retrieved from http://www.effective-states.org/wp-content/ uploads/working_papers/final-pdfs/esid_wp_50_ chopra.pdf

Corbett, J. (2019). Where do leaders come from? Birmingham: Developmental Leadership Program.

Department for International Development. (2004). Senior leaders political management of pro-poor initiatives in an era of centrists: Understanding 'political will' (Vol. 3). London: Her Majesty's Government.

Dutta, P., Murgai, R., Ravallion, M., \& van de Walle, D. (2014). Right to work? assessing India's employment guarantee scheme in Bihar (1st ed.). Washington, DC: World Bank Group.

Freud, E. J. (2015). NREGA under attack: The erosion of India's employment guarantee program and the possible effects on women (Paper No. 142). Annandaleon-Hudson, NY: Bard College. 
Ghosh, J. (2015, February 5). India's rural employment programme is dying a death of funding cuts. The Guardian. Retrieved from https://www.theguardian. com/global-development/2015/feb/05/india-ruralemployment-funding-cuts-mgnrega

Gowda, M. V. R., \& Batra, K. (2019). MGNREGA survived Modi govt's neglect and derision, it will be up to new regime to fix it. The Print. Retrieved from https://theprint.in/opinion/mgnrega-survivedmodi-govts-neglect-and-derision-it-will-be-up-tonew-regime-to-fix-it/219460

Gwatkin, D. R. (1979). Political will and family planning: The implications of India's Emergency experience. Population and Development Review, 5(1), 29-59.

Hammergren, L. (1998). Political will, constituency building, and public support in rule of law programs (Democracy Fellows Program Series PN-ACD-023). Washington, DC: United States Agency for International Development.

Hudson, D., Mcloughlin, C., Roche, C., \& Marquette, H. (2018). Inside the black box of political will: 10 years of findings from the Developmental Leadership Program. Birmingham: Developmental Leadership Program.

Indian National Congress. (2004). Manifesto 2004 [Brochure]. New Delhi: All India Congress Committee.

Joshua, A., \& Sriram, J. (2015, February 27). Your law was not flawless, Modi tells Congress. The Hin$d u$. Retrieved from https://www.thehindu.com/ news/national/mnrega-monument-to-failure-ofcongress-govts-modi/article10701735.ece

Kotwal, A., Ghatak, M., \& Ghosh, P. (2014). Growth in the time of UPA: Myths and reality. Economic \& Political Weekly, 49(16), 35-43.

Kpundeh, S. J. (1998). Political will in fighting corruption. In K. Sahr \& I. Hors (Eds.), Corruption and integrity improvement initiatives in developing countries (pp. 91-110). Paris: United Nations Development Programme/Organisation for Economic Co-operation and Development.

Krishna, U. (2019, June 5). NREGA: How political will impacted implementation. The Financial Express. Retrieved from https://www.financialexpress.com/ opinion/nrega-how-political-will-impactedimplementation/1598304

Lack of political will holding India back, says Parekh. (2014, December 20). Firstpost. Retrieved from https://www.firstpost.com/business/lack-ofpolitical-will-holding-india-back-says-parekh340199.html

Leftwich, A., \& Wheeler, C. (2011). Politics, leadership and coalitions in development: A research and policy workshop report. Birmingham: Developmental Leadership Program.

Manor, J. (2011). Did the central government's poverty initiatives help to re-elect it? In L. Saez \& G. Singh (Eds.), New dimensions of politics in India: The unit- ed progressive alliance in power (pp. 13-25). London: Routledge.

Manor, J., \& Duckett, J. (2017). The significance of political leaders for social policy expansion in Brazil, China, India and South Africa. Commonwealth \& Comparative Politics, 55(3), 303-327.

Mcloughlin, C. (2015). Researching state legitimacy: A political approach to a political problem (Research Paper No. 36). Birmingham: Developmental Leadership Program.

Mcloughlin, C., \& Batley, R. (2012). The politics of what works in service delivery: An evidence based review (Working Paper No. 6). Manchester: University of Manchester.

MGNREGA wage-material ratio to be maintained at district level, says govt, draws flak. (2016, April 9). The Economic Times. Retrieved from https:// economictimes.indiatimes.com/news/economy/ policy/mgnrega-wage-material-ratio-to-bemaintained-at-district-level-says-govt-draws-flak/ articleshow/51755563.cms?utm_source=contentof interest\&utm_medium=text\&utm_campaign=cppst

Ministry of Rural Development. (2010). Mahatma Gandhi National Rural Employment Guarantee Act 2005. New Delhi: Government of India.

Ministry of Rural Development. (2013). Frequently asked questions (FAQs) on MGNREGA operational guidelines: 2013. New Delhi: Government of India. Retrieved from https://nrega.nic.in/Circular_ Archive/archive/nrega_doc_FAQs.pdf

Ministry of Rural Development. (2020a). Mahatma Gandhi National Rural Employment Guarantee Act. Government of India. Retrieved from www.nrega.nic.in

Ministry of Rural Development. (2020b). MGNREGA public data portal. Government of India. Retrieved from https://nregarep2.nic.in/netnrega/dynamic2/ dynamicreport_new4.aspx

Modi government praises UPA's MGNREGA as scheme completes 10 years tomorrow. (2016, February 1). The Economic Times. Retrieved from https:// economictimes.indiatimes.com/news/politics-andnation/modi-government-praises-upas-mgnrega-asscheme-completes-10-years-tomorrow/ articleshow/50804872.cms

Pankaj, A. (2017). Shift in MGNREGS from UPA to NDA. Economic \& Political Weekly, 52(33), 59-68.

Pawariya, A. (2017, August 22). How Narendra Modi's NREGA differs from Sonia Gandhi's. Swarajya. Retrieved from https://swarajyamag.com/economy/ how-narendra-modis-nrega-differs-from-soniagandhis

Post, L. A., Raile, A. N. W., \& Raile, E. D. (2010). Defining political will. Politics \& Policy, 38(4), 653-676.

Roberts, D. (2017). What is "political will," anyway? Scholars take a whack at defining it. Vox. Retrieved from https://www.vox.com/2016/2/17/11030876/ political-will-definition

Rose, P., \& Greeley, M. (2006). Education in fragile states: 
Capturing lessons and identifying good practice. Sussex: Institute of Development Studies.

Save our babies: Political will is needed to bring down India's shameful levels of newborn mortality. (2018, February 21). The Times of India. Retrieved from https://timesofindia.indiatimes.com/blogs/toieditorials/save-our-babies-political-will-is-neededto-bring-down-indias-shameful-levels-of-newbornmortality

Second Administrative Reforms Commission. (2006). Unlocking human capital: entitlements and governance: a case study (Report No. 2). New Delhi: Government of India.

Shankar, S., \& Gaiha, R. (2013). Battling corruption: Has NREGA reached India's rural poor? (1st ed.). Oxford: Oxford University Press.

Singh, S. (2014, May 16). Manmohan Singh and his economics. Livemint. Retrieved from https://www. livemint.com/Opinion/HMZuBDoZysg3Bt4UO1tUcL/
Manmohan-Singh-and-his-economics.html

Tiwari, S. (2019). Explaining the difference between the government finances reported in the Economic Survey and the Union Budget 2019-20. The PRS Blog. Retrieved from https://www.prsindia.org/ theprsblog/explaining-difference-betweengovernment-finances-reported-economic-surveyand-union

Vijayabaskar, M., \& Balagopal, G. (2019). The politics of poverty alleviation strategies in India (Working Paper 2019-7). Geneva: United Nations Research Institute for Social Development.

Yadav, Y., \& Palshikar, S. (2009). Between fortuna and virtu: Explaining the congress' ambiguous victory in 2009. Economic \& Political Weekly, 44(39), 33-46.

Zimmermann, L. (2013). Why guarantee employment? Evidence from a large Indian public-works program. Ann Arbor, MI: University of Michigan.

\section{About the Authors}

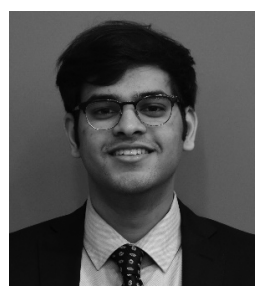

Ujjwal Krishna is a Specialist Doctoral Research Scholar at the Institute for Human Security and Social Change. His PhD research on the political economy of development policy involves working with the Australian Government's Department of Foreign Affairs and Trade on its aid investments in leadership and coalitions. He was previously with ICRIER, where he supported the Government of India's digital development interests, particularly at ICANN 65 in Marrakech. Ujjwal holds an MA (Distinction) in Development Studies from IDS, Sussex, and a BA (Hons) in Economics from the University of Delhi.

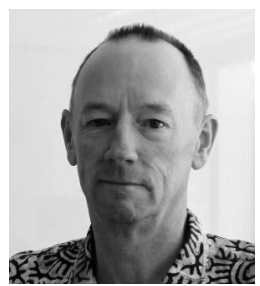

Chris Roche is Professor of Development Practice and Director of the Institute for Human Security and Social Change at La Trobe University. He is also Deputy Director (Impact) of the Developmental Leadership Program, an international research program which explores how leadership, power and political processes drive or block successful development. Prior to joining La Trobe in 2012, Chris worked for over 25 years for International NGOs as a Project Manager, Evaluator, Policy Researcher, and as a Director. 